\title{
Absence or pharmacological blocking of placental P-glycoprotein profoundly increases fetal drug exposure
}

\author{
Johan W. Smit, ${ }^{1}$ Maarten T. Huisman, ${ }^{1}$ Olaf van Tellingen, ${ }^{2}$ Hugh R. Wiltshire, ${ }^{3}$ \\ and Alfred H. Schinkel ${ }^{1}$ \\ ${ }^{1}$ Division of Experimental Therapy, and \\ ${ }^{2}$ Department of Clinical Chemistry, the Netherlands Cancer Institute, 1066 CX Amsterdam, the Netherlands \\ ${ }^{3}$ Drug Development, Roche Products Ltd., Welwyn Garden City, Hertsfordshire AL7 3AY,United Kingdom
}

Address correspondence to: A.H. Schinkel, Division of Experimental Therapy, the Netherlands Cancer Institute, Plesmanlaan 121, 1066 CX Amsterdam, the Netherlands. Phone: 31-20-5122046; Fax: 31-20-5122050; E-mail: alfred@nki.nl.

Received for publication July 26, 1999, and accepted in revised form October 5, 1999.

\begin{abstract}
It was recently shown that naturally occurring Mdr1a mutant fetuses of the CF-1 outbred mouse stock have no placental Mdr1a P-glycoprotein (P-gP) and that this absence is associated with increased sensitivity to avermectin, a teratogenic pesticide. To further define the role of placental drug-transporting $\mathrm{P}-\mathrm{gp}$ in toxicological protection of the fetus, we used mice with a targeted disruption of the $M d r 1 a$ and $M d r 1 b$ genes. $M d r 1 a^{+/-} / 1 b^{+/-}$females were mated with $M d r 1 a^{+/-} / 1 b^{+/-}$males to obtain fetuses of 3 genotypes $\left(M d r 1 a^{+/+} / 1 b^{+/+}, M d r 1 a^{+/-} / 1 b^{+/-}\right.$, and $\left.M d r 1 a^{-/-} / 1 b^{-/-}\right)$in a single mother. Intravenous administration of the P-gp substrate drugs $\left[{ }^{3} \mathrm{H}\right]$ digoxin, $\left[{ }^{14} \mathrm{C}\right]$ saquinavir, or paclitaxel to pregnant dams revealed that 2.4-, 7-, or 16-fold more drug, respectively, entered the $M d r 1 a^{-/-} / 1 b^{-/-}$fetuses than entered wild-type fetuses. Furthermore, placental P-gp activity could be completely inhibited by oral administration of the P-gp blockers PSC833 or GG918 to heterozygous mothers. Our findings imply that the placental drug-transporting P-gp is of great importance in limiting the fetal penetration of various potentially harmful or therapeutic compounds and demonstrate that this P-gp function can be abolished by pharmacological means. The latter principle could be applied clinically to improve pharmacotherapy of the unborn child.
\end{abstract}

J. Clin. Invest. 104:1441-1447 (1999).

\section{Introduction}

The drug-transporting P-glycoprotein (P-gP), originally discovered in multidrug resistant (MDR) tumor cells (1), belongs to the superfamily of ATP binding cassette proteins $(2,3)$. In humans, P-gp is encoded by the MDR1 gene, whereas in mice the $M d r 1 a$ and $M d r 1 b$ genes each encode a drug-transporting P-gp isoform $(4,5)$. After the discovery of the human MDR1 and the murine Mdr1a and $M d r 1 b$ genes, it was shown that drug-transporting Pgps are expressed in a variety of normal tissues, mostly of epithelial origin (6-8). Because the MDR1, Mdr1a, and Mdr1b P-gps have largely overlapping drug transport specificity and organ distribution, it is believed that these transporters have similar roles in humans and mice $(3,9)$. The Mdr1a knockout mouse model has proved a very useful tool for elucidating the contributions of drug-transporting P-gp in drug pharmacology. It has been shown that this P-gp isoform limits brain and testis penetration (10) as well as intestinal uptake of potentially harmful or therapeutic hydrophobic compounds $(11,12)$. Hence, one major physiological role of the drugtransporting P-gps is the protection of an organism against potentially toxic compounds that can be encountered in the environment.

Recently, Lankas et al. provided evidence that placental P-gp may also play an important role in the protection of the developing fetus (13). They showed that the placental Mdr1a P-gp is present in the fetus-derived epithelial cells that make up the exchange border between the fetal and maternal blood circulation, and that P-gp faces the maternal blood side (13). Using naturally occurring Mdr1a mutant mice of the CF-1 outbred mouse stock (14) that lack the Mdr1a P-gp, and therefore phenotypically resemble mice with a targeted disruption of Mdr1a (10), it was shown that absence of Mdr1a P-gp is associated with enhanced sensitivity of the fetus to an isomer of the pesticide avermectin (13). They further showed that enhanced fetal drug penetration paralleled the increased avermectin sensitivity in Mdrla mutant fetuses. Hence, functional Mdr1a P-gp may largely limit the fetal penetration of this compound $(13,15)$.

We used the targeted $M d r 1 a / M d r 1 b$ knockout (Mdr1 $\left.\mathrm{a}^{-/-} / 1 \mathrm{~b}^{-/-}\right)$mouse model (16) in a homogeneous FVB genetic background to assess whether the drug-transporting P-gp at the fetoplacental unit serves to limit placental transfer of a range of other P-gp substrate drugs from the maternal circulation into the fetus. Use of $M d r 1 a^{-/-} / 1 b^{-/-}$mice instead of $\mathrm{Mdrla}^{-/-}$mice has the advantage of possible complications that might arise from a low expression placental Mdr1b; although Lankas et al. demonstrated that Mdr1a P-gp is the main functional Pgp isoform in placenta, some Mdr1b P-gp was also detected (13). Furthermore, we investigated whether the transfer of drugs across the placenta could be modulated by potent P-gp inhibitors such as PSC833 or GG918, because this could have important toxicological and therapeutic 
implications. We tested digoxin, saquinavir, and paclitaxel as model P-gp substrate drugs in view of their previously demonstrated highly P-gp-dependent pharmacokinetic behavior in mice $(11,12,17)$.

\section{Methods}

Chemicals. $\left[{ }^{3} \mathrm{H}\right]$ digoxin $(16.0 \mathrm{Ci} / \mathrm{mmol})$ was from DuPont NEN Life Science Products (Boston, Massachusetts, USA). Paclitaxel was from Sankyo Co. (Tokyo, Japan). Saquinavir and $\left[{ }^{14} \mathrm{C}\right]$ saquinavir $(26.5 \mu \mathrm{Ci} / \mathrm{mg})(18)$ were provided by Roche Discovery Welwyn (Welwyn Garden City, United Kingdom). PSC833 was a gift of Novartis Pharma Inc. (Basel, Switzerland), and GG918 (formerly designated GF120918) was kindly provided by GlaxoWellcome Inc. (Research Triangle Park, North Carolina, USA). Digoxin, Cremophore EL, hydroxypropylmethylcellulose, and Tween 80 were from Sigma Chemical Co. (St. Louis, Missouri, USA). Deionized water was obtained using the Milli-Q Plus System (Millipore Corp., Bedford,

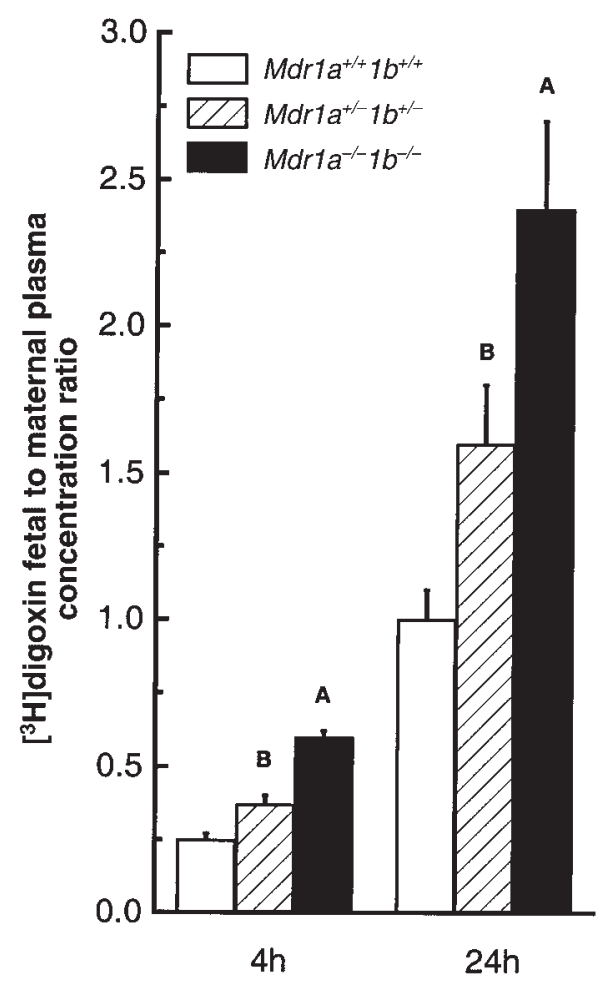

\section{Figure 1}

Ratio of $\left[{ }^{3} \mathrm{H}\right]$ digoxin fetal concentration to maternal plasma concentration. Heterozygous mice were mated, and $\left[{ }^{3} \mathrm{H}\right]$ digoxin $(0.05$ $\mathrm{mg} / \mathrm{kg}$ ) was administered intravenously to pregnant dams at gestation day 15. At 4 hours or 24 hours after dosing, dams were euthanized, and fetuses from 3 litters were collected. Maternal plasma and fetal drug content and genotypes were determined as described in Methods. Open bars indicate wild-type values, hatched bars heterozygous values, and black bars $M d r 1 a^{-/-} / 1 b^{-/-}$values. Values are expressed as mean $\left[{ }^{3} \mathrm{H}\right]$ digoxin concentration in fetal tissues $(\mathrm{ng} / \mathrm{g})$ normalized to maternal plasma $\left[{ }^{3} \mathrm{H}\right]$ digoxin concentration $(\mathrm{ng} / \mathrm{mL})$. Six to 16 fetuses of each genotype were analyzed. Average maternal plasma concentrations were $19.2 \pm 1.6 \mathrm{ng} / \mathrm{mL}$ and $1.1 \pm 0.15 \mathrm{ng} / \mathrm{mL}$ at 4 and 24 hours after digoxin administration, respectively. Error bars indicate SD. ${ }^{A} P<0.0001,{ }^{B} P<0.005$, vs. wild-type fetuses in pairwise comparison.
Massachusetts, USA). BSA was from Boehringer Mannheim GmbH (Mannheim, Germany). Taq DNA polymerase and dNTP were purchased from GIBCO BRL (Breda, the Netherlands).

Drug distribution studies. Animals were housed and handled according to institutional guidelines complying with Dutch legislation. In order to exclude any potential contribution of putative placental expression of $\mathrm{Mdr} 1 \mathrm{~b}$ P-gp $(8,13)$, mice that were heterozygous for a targeted disruption of both the Mdrla and $M d r 1 b$ genes $\left(M d r 1 a^{+/-} / 1 b^{+/-}\right.$mice) were used throughout. Mice of an FVB genetic background, 10-14 weeks of age, were used in all experiments. All animals had free access to standard chow (AM-II; Hope Farms, Woerden, the Netherlands) and acidified water, and were kept in a $12 \mathrm{~h} / 12 \mathrm{~h}$ light/dark cycle at a constant room temperature of $22^{\circ} \mathrm{C}$. PSC833 stock solution was in ethanol/Cremophore EL (35:65, vol/vol) at $50 \mathrm{mg} / \mathrm{mL}$ and diluted into $5 \%$ (wt/vol) glucose to achieve $5 \mathrm{mg} / \mathrm{mL}$ PSC833. GG918 was sus-

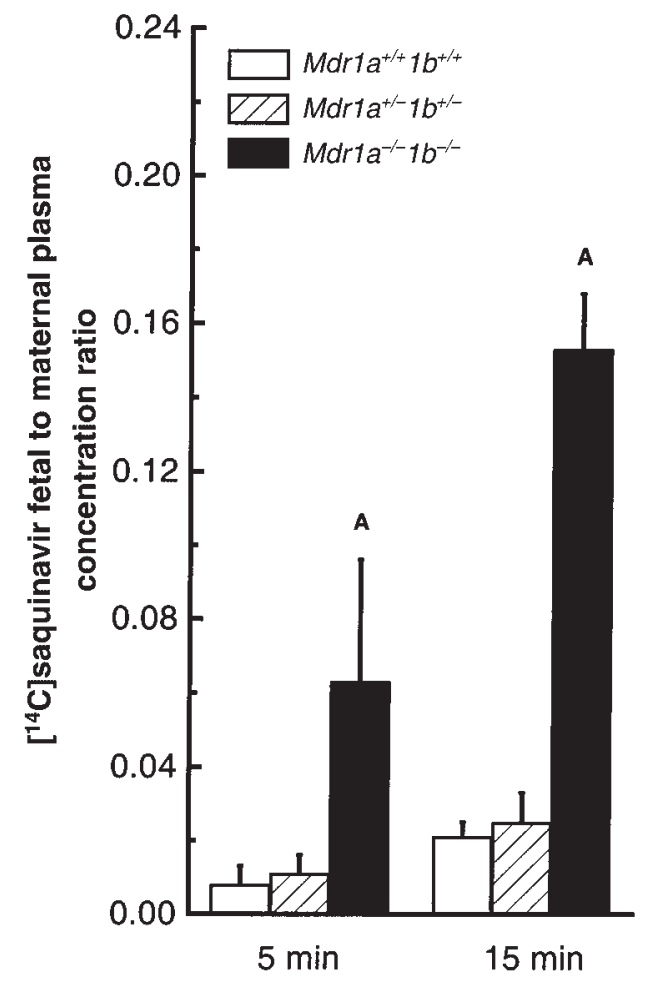

Figure 2

Ratio of $\left[{ }^{14} \mathrm{C}\right]$ saquinavir fetal concentration to maternal plasma concentration. Heterozygous mice were mated, and $\left[{ }^{14} \mathrm{C}\right]$ saquinavir $(1$ $\mathrm{mg} / \mathrm{kg}$ ) was administered intravenously to pregnant dams at gestation day 15. At 5 or15 minutes after dosing, dams were euthanized, and fetuses from 4 litters were collected. Maternal plasma and fetal drug content and genotypes were determined as described in Methods. Open bars indicate wild-type values, hatched bars heterozygous values, and black bars Mdr $1 a^{-1-} / 1 b^{-/-}$values. Values are expressed as mean $\left[{ }^{14} \mathrm{C}\right]$ saquinavir concentration in fetal tissues normalized to maternal plasma $\left[{ }^{14} \mathrm{C}\right]$ saquinavir concentration. Four to 27 fetuses of each genotype were analyzed. Average maternal plasma concentration was $429 \pm 32 \mathrm{ng} / \mathrm{mL}$ and $145.9 \pm 16$ $\mathrm{ng} / \mathrm{mL}$ at 5 minutes and 15 minutes after $\left[{ }^{14} \mathrm{C}\right]$ saquinavir administration, respectively. All animals had also received oral administration of vehicle 2 hours before intravenous drug administration for proper comparison to PSC833-treated mice (see experiment described in Table 3). Error bars indicate SD. ${ }^{A} P<0.005$ vs. wild-type fetuses in pairwise comparison. 
pended in a formulation of hydroxypropylmethylcellulose, Tween 80, and $\mathrm{H}_{2} \mathrm{O}(0.5: 1: 98.5$, wt/wt/vol) for oral administration at $2.5 \mathrm{mg} / \mathrm{mL}$. Animals were treated with $50 \mathrm{mg} / \mathrm{kg}$ PSC833, $25 \mathrm{mg} / \mathrm{kg}$ GG918, or a corresponding amount of vehicle by gavage in a volume of $10 \mu \mathrm{L}$ drug solution per gram body weight under a light Metofane (Mallinckrodt Veterinary, Mundelein, Illinois, USA) anesthesia, 2 hours before administration of the tested drugs. Intravenous injections of $\left[{ }^{3} \mathrm{H}\right]$ digoxin, $\left[{ }^{14} \mathrm{C}\right]$ saquinavir, or paclitaxel were given at the respective dosages of 2,3 , and $6.67 \mu \mathrm{L}$ per gram body weight. (Dosages ranged from $0.05 \mathrm{mg} / \mathrm{kg}$ to $10 \mathrm{mg} / \mathrm{kg}$ body weight; see figure legends for specific conditions.)

Fetal drug distribution studies were performed using pregnant female heterozygous $\left(M d r 1 a^{+/-} / 1 b^{+/-}\right)$mice on gestation day 15 after mating to heterozygous males. This way, offspring of 3 different genotypes can be generated in 1 single mother. Pregnant dams each received 1-2 $\mu \mathrm{Ci}$ (37-74 kilobecquerels) of the radioactively labeled drug. Animals were sacrificed at appropriate time points. Plasma and some of the major organs were collected. Fetuses were sacrificed immediately after removal from the pregnant uterus and put on dry ice. When appropriate, fetal drug distribution was expressed as the ratio of total fetal drug concentration to maternal plasma concentration, designated "drug ratio." Levels of $\left[{ }^{3} \mathrm{H}\right]$ digoxin were determined as drug equivalent per weight or volume because digoxin is only slowly metabolized in mice (17). Unchanged saquinavir in plasma was determined by HPLC according to Van Heeswijk et al. (19). Fetal saquinavir levels were below HPLC detection limits, so saquinavir levels in the fetuses were determined as drug equivalent per weight. Fetal and maternal plasma paclitaxel levels were determined using HPLC (11).

For scintillation counting, fetuses and maternal organs were homogenized in 4\% (wt/vol) BSA. Samples (250-1000 $\mu \mathrm{L})$ were solubilized in Soluene-350/isopropanol (1:2, $\mathrm{vol} / \mathrm{vol}$ ) or in SOLVABLE (Packard Instrument Co., Groningen, the Netherlands) for $1-2$ hours at $40^{\circ} \mathrm{C}$ and then transferred to Hionic-Fluor or Ultima Gold scintillation cocktail (Packard Bioscience B.V.), respectively.

Genotype analysis. Fetal genotypes $\left(\mathrm{Mdrla}^{+/+} / 1 \mathrm{~b}^{+/+}\right.$, $M d r 1 a^{+/-} / 1 b^{+/-}$, or $\left.M d r 1 a^{-/-} / 1 b^{-/-}\right)$were established as follows. Genomic DNA for PCR was extracted from fetal tissue homogenates. Briefly, $10 \mu \mathrm{L}$ of homogenized fetal samples were mixed with $10 \mu \mathrm{L}$ lysis buffer $(50 \mathrm{mM}$ Tris- $\mathrm{HCl}$ at pH 8.5, $20 \mathrm{mM} \mathrm{NaCl}, 1 \mathrm{mM}$ EDTA, and 1\% vol/vol Triton $\mathrm{X}-100)$ and proteinase $\mathrm{K}(2 \mathrm{mg} / \mathrm{mL})$. Samples were incubated for 30 minutes at $55^{\circ} \mathrm{C}$, with vigorous vortexing 15 minutes into the incubation period. Then $180 \mu \mathrm{L}$ water was added, and the samples were boiled for 5 minutes and then put on ice. Debris was spun down and $1-\mu \mathrm{L}$ samples were taken with which to perform PCR. The primers used were (all primer sequences denoted in the $5^{\prime}$ to $3^{\prime}$ direction):

Mdr1a 5': CAG CTC CAT CCA ACA ACT TC and 3': GAC ACA GGT ACT GTC CAC AG; Mdr1b 5': GAG AAA CCA TGT CCT TCC AG and $3^{\prime}$ : AAG CTG TGC ATG ATT CTG GG; neo 5': TGT CAA GAC CGA CCT GTC CG and 3': TAT TCG GCA AGC AGG CAT CG; bygro 5': ATG TCC TGC GGG TAA ATA GC and 3': CGT CAG GAC ATT GTT GGA GC.

DNA fragments were amplified using a PTC-200 Thermal Cycler (MJ Research Inc., Watertown, Massachusetts,
USA) under the following conditions: one cycle at $94^{\circ} \mathrm{C}$ for 3 minutes, and 35 cycles at $94^{\circ} \mathrm{C}$ for 1 minute, $58^{\circ} \mathrm{C}$ for 1 minute and $72^{\circ} \mathrm{C}$ for 1 minute. DNA was size separated on a $1.5 \%$ (wt/vol) Tris-Acetate-EDTA buffer-agarose gel containing $1.0 \mu \mathrm{g} / \mathrm{mL}$ ethidium bromide; fetal genotypes were established subsequently.

Statistical analysis. The Mann-Whitney $U$ test was used to perform statistical significance analysis on differences between 2 sets of data. $P<0.05$ was considered statistically significant.

\section{Results}

We aimed to assess the contribution of placental drugtransporting P-gp to the prevention of drug passage into the fetus. Placental P-gp is derived from the fetus (13), and each mouse fetus induces the formation of its own placenta. Therefore we used pregnant heterozygous $\left(M d r 1 a^{+/-} / 1 b^{+/-}\right)$dams that had been mated to $M d r 1 a^{+/-} / 1 b^{+/-}$males to obtain offspring of all 3 genotypes

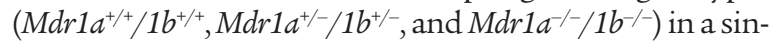
gle mother (the Mdr1a and $M d r 1 b$ genes are very closely linked, and hence behave essentially as 1 locus). This allowed us to investigate fetal drug distribution under cir-

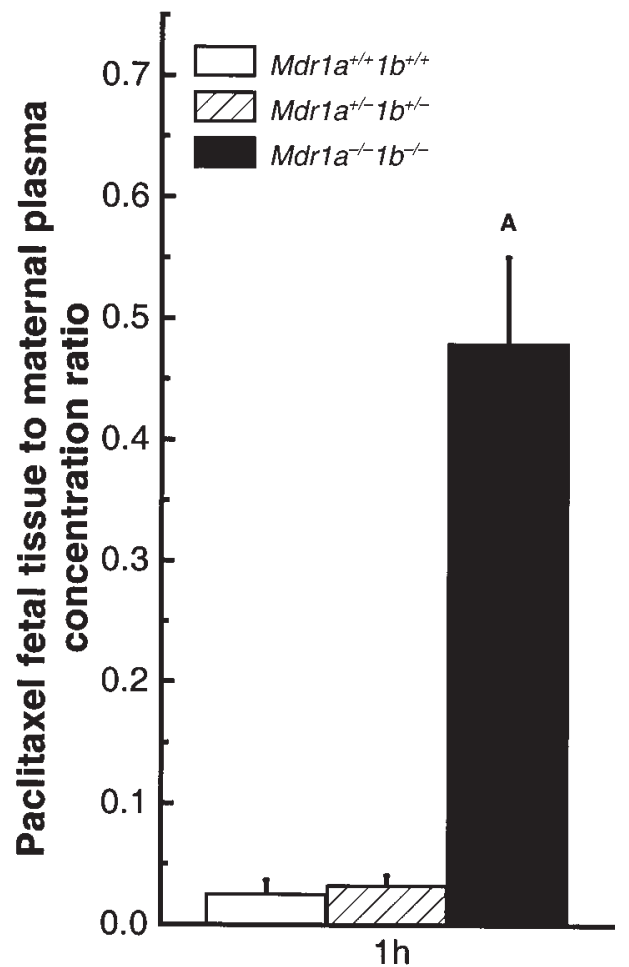

Figure 3

Ratio of paclitaxel fetal concentration to maternal plasma concentration. Heterozygous mice were mated, and paclitaxel $(10 \mathrm{mg} / \mathrm{kg})$ was administered intravenously to pregnant dams at gestation day 15 . At 1 hour after dosing, dams were euthanized, and fetuses from 4 litters were collected. Maternal plasma and fetal drug content and genotypes were determined as described in Methods. Open bars indicate wild-type values, hatched bars heterozygous values, and black bars $M d r 1 a^{-1-} / 1 b^{-/-}$values. Values are expressed as mean paclitaxel concentration in fetal tissues $(\mathrm{ng} / \mathrm{g})$ normalized to maternal plasma paclitaxel concentration $(\mathrm{ng} / \mathrm{mL})$. Twelve to 14 fetuses of each genotype were analyzed. The average maternal plasma concentration was $1949 \pm 219 \mathrm{ng} / \mathrm{mL}$. Error bars indicate SD. ${ }^{A} P<0.0001$ vs. wild-type fetuses in pairwise comparison. 
Table 1

Effect of PSC833 on maternal plasma and fetal tissue levels of radioactivity 4 hours after intravenous administration of $\left[{ }^{3} \mathrm{H}\right]$ digoxin

$\left[{ }^{3} \mathrm{H}\right]$ digoxin + vehicle $\left[{ }^{3} \mathrm{H}\right]$ digoxin + PSC833 PSC833/vehicle ratio

$\begin{array}{lrrr}M d r 1 a^{+/+} / 1 b^{+/+} & 4.8 \pm 0.5 & 12.0 \pm 1.1^{\mathrm{A}} & 2.5 \\ M d r 1 a^{+/-} / 1 b^{+/-} & 7.1 \pm 0.8 & 12.6 \pm 1.6^{\mathrm{B}} & 1.8 \\ M d r 1 a^{-/-} / 1 b^{-/-} & 10.9 \pm 1.1 & 14.5 \pm 2.0 & 1.3 \\ \text { Plasma } & 19.2 \pm 1.6 & 18.0 \pm 2.1 & 0.9\end{array}$

Results are presented as mean $\pm \mathrm{SD}$ in $\mathrm{ng}\left[{ }^{3} \mathrm{H}\right]$ digoxin equivalent per gram or per $\mathrm{mL}$. Three pregnant $M d r 1 a^{+/-} / 1 b^{+/-}$dams at gestation day 15 received PSC833 $(50 \mathrm{mg} / \mathrm{kg})$ or vehicle alone by gavage 2 hours before the intravenous injection of $\left[{ }^{3} \mathrm{H}\right]$ digoxin $(0.05 \mathrm{mg} / \mathrm{kg})$. Data presented in Figure 1 for vehicle-treated dams were included in this Table for comparison. ${ }^{A} P<0.005,{ }^{B} P$ $<0.0001$ vs. vehicle-treated dams. Six to 16 fetuses of each genotype were analyzed.

cumstances where placental exposure to a drug from maternal blood is identical for fetuses of all 3 genotypes. Figure 1 represents the ratio of fetal tissue drug concentration to maternal plasma concentration (drug ratio) of the cardiac glycoside $\left[{ }^{3} \mathrm{H}\right]$ digoxin, after intravenous administration at $0.05 \mathrm{mg} / \mathrm{kg}$ to heterozygous pregnant dams at gestation day 15. A 2.2- and 2.4-fold higher $\left[{ }^{3} \mathrm{H}\right]$ digoxin ratio was observed in $M d r 1 a / 1 b$ null fetuses than in wildtype fetuses at 4 and 24 hours after $\left[{ }^{3} \mathrm{H}\right]$ digoxin administration, respectively. Drug penetration into heterozygous fetuses was also significantly higher than into wild-type fetuses. In fact, both at 4 and 24 hours, the $\left[{ }^{3} \mathrm{H}\right]$ digoxin ratios of the heterozygous fetuses were intermediate between the $\left[{ }^{3} \mathrm{H}\right]$ digoxin ratios observed in the wild-type and in the $M d r 1 a^{-/-} / 1 b^{-/-}$fetuses.

Using the same experimental approach, we next investigated whether placental P-gp could limit fetal penetration of saquinavir, an HIV protease inhibitor drug and a good P-gp substrate $(12,20,21)$. We found that upon intravenous administration of $1 \mathrm{mg} / \mathrm{kg}\left[{ }^{14} \mathrm{C}\right]$ saquinavir to pregnant dams, the absence of drug-transporting Pgp resulted in much higher $\left[{ }^{14} \mathrm{C}\right]$ saquinavir levels in $M d r 1 a / 1 b$ null fetuses than in wild-type fetuses (Figure $2)$. At 5 and 15 minutes after drug administration, $\left[{ }^{14} \mathrm{C}\right]$ saquinavir ratios were 5 - to 7 -fold higher in the Mdr1a/1b null fetuses. Unlike the digoxin levels, $\left[{ }^{14} \mathrm{C}\right]$ saquinavir levels in the heterozygous fetuses were comparable to those in the wild-type fetuses. Of note, the absolute fetal $\left[{ }^{14} \mathrm{C}\right]$ saquinavir concentration was already at maximal levels just 5-15 minutes after intravenous administration, indicating that saquinavir rapidly distributes through the placenta and into the fetus, especially in the absence of P-gp. Fetuses harvested at later time points showed that fetal $\left[{ }^{14} \mathrm{C}\right]$ saquinavir concentration decreased after 15 minutes (data not shown).

We also tested the effect of placental P-gp on the transfer of the anticancer drug paclitaxel into the fetus, because this drug is an excellent P-gp substrate in both humans and mice (11). One hour after intravenous paclitaxel administration $(10 \mathrm{mg} / \mathrm{kg})$ to pregnant $M d r 1 a^{+/-} / 1 b^{+/-}$dams, the animals were sacrificed and the nonmetabolized paclitaxel concentration in maternal plasma and fetal tissue homogenates were measured by HPLC. Observed paclitaxel ratios were approximately 16-fold higher in the $M d r 1 a / 1 b$ null fetuses than in the wild-type fetuses (Figure $3)$. In a small-scale pilot experiment, prolonged exposure of fetuses to paclitaxel revealed that paclitaxel levels in the fetus increased over time, whereas maternal plasma levels decreased (determined 8 hours after intravenous drug administration). This resulted in higher fetal tissue/maternal plasma paclitaxel ratios. At the same time, the difference between the paclitaxel ratios of $M d r 1 a / 1 b$ null fetuses and wildtype fetuses increased to 25 -fold (data not shown). The paclitaxel ratios in wild-type and heterozygous fetuses were similar 1 hour after drug administration (Figure 3), as was the case for $\left[{ }^{14} \mathrm{C}\right]$ saquinavir. This indicates that the P-gp level in the placenta of $M d r 1 a^{+/-} / 1 b^{+/-}$fetuses is still sufficient to limit the passage of large amounts of paclitaxel and $\left[{ }^{14} \mathrm{C}\right]$ saquinavir.

We next investigated the possibility of modulating the placental permeability of certain drugs by blocking P-gp activity. P-gp blockers such as PSC833 and GG918 have been developed for in vivo P-gp inhibition, and are currently being used in trials to reverse MDR in tumors of cancer patients. Because our previous work showed that orally administered PSC833 was able to inhibit drug-transporting P-gp-mediated digoxin transport completely in the intestine, and extensively in the blood-brain barrier (22), this compound was tested first. Table 1 presents the fetal $\left[{ }^{3} \mathrm{H}\right]$ digoxin concentration data obtained from pregnant $M d r 1 a^{+/-} / 1 b^{+/-}$dams pretreated with oral PSC833 $(50 \mathrm{mg} / \mathrm{kg})$ or vehicle alone, 2 hours before intravenous digoxin administration. With PSC833 treatment, comparable amounts of $\left[{ }^{3} \mathrm{H}\right]$ digoxin were observed in the fetuses regardless of genotype. Moreover, the levels of $\left[{ }^{3} \mathrm{H}\right]$ digoxin in PSC833-treated fetuses of all genotypes were similar to those in vehicle-treated $M d r 1 a / 1 b$ null fetuses, and were at least 2.5 -fold higher than in vehicle-treated wild-type fetuses (Table 1). Therefore, the placental P-gp function can be efficiently blocked by oral PSC833. Of note, the maternal plasma levels in vehicle- and PSC833-treated heterozygous dams were similar, suggesting that there was no substantial alteration in digoxin plasma clearance over a 4-hour period with oral PSC833 pretreatment. Table 2 summarizes the $\left[{ }^{3} \mathrm{H}\right]$ digoxin distribution data obtained from several tissues from the treated dams. Brain digoxin levels increased 7-fold $(P<0.05)$ with PSC833 pretreatment of the pregnant heterozygous dams as compared to vehicletreated dams. This parallels our earlier finding that orally administered PSC833 can quite effectively block P-gP at the blood-brain barrier in wild-type mice (22).

With oral PSC833 pretreatment, comparable amounts of $\left[{ }^{14} \mathrm{C}\right]$ saquinavir also distributed into the fetuses of all 3

\section{Table 2}

Effect of PSC833 on maternal plasma and tissue levels of radioactivity 4 hours after intravenous administration of $\left[{ }^{3} \mathrm{H}\right]$ digoxin

\begin{tabular}{lccc} 
& {$\left[{ }^{3} \mathrm{H}\right]$ digoxin + vehicle } & {$\left[{ }^{3} \mathrm{H}\right]$ digoxin + PSC833 } & PSC833/vehicle ratio \\
Kidney & $18.0 \pm 2.6$ & $13.0 \pm 1.8^{\mathrm{A}}$ & 0.72 \\
Liver & $45.3 \pm 10.9$ & $41.2 \pm 5.4$ & 0.91 \\
Brain & $2.5 \pm 0.3$ & $18.5 \pm 0.7^{\mathrm{A}}$ & 7.4 \\
Spleen & $7.7 \pm 0.9$ & $8.8 \pm 2.0$ & 1.1 \\
Plasma & $19.2 \pm 1.6$ & $18.0 \pm 2.1$ & 0.94 \\
\hline
\end{tabular}

Results are presented as mean $\pm \mathrm{SD}$ in $\mathrm{ng}\left[{ }^{3} \mathrm{H}\right]$ digoxin equivalent per gram or per $\mathrm{mL}$. Three pregnant $\mathrm{Mdr} 1 \mathrm{a}^{+/-} / 1 b^{+/-}$dams at gestation day 15 received PSC833 (50 $\mathrm{mg} / \mathrm{kg}$ ) or vehicle alone by gavage 2 hours before the intravenous injection of $\left[{ }^{3} \mathrm{H}\right.$ ] digoxin at $0.05 \mathrm{mg} / \mathrm{kg}$. ${ }^{A} P<0.05$ vs. vehicle-treated mice. 
Table 3

Effect of PSC833 on maternal plasma and fetal tissue levels of radioactivity 5 minutes and 15 minutes after intravenous administration of $\left[{ }^{14} \mathrm{C}\right]$ saquinavir $(1 \mathrm{mg} / \mathrm{kg})$

\begin{tabular}{|c|c|c|c|}
\hline & $\begin{array}{c}{\left[{ }^{14} \mathrm{C}\right] \text { saquinavir }+} \\
\text { vehicle }\end{array}$ & $\begin{array}{c}{\left[{ }^{14} \mathrm{C}\right] \text { saquinavir + }} \\
\text { PSC } 833\end{array}$ & $\begin{array}{c}\text { PSC833/vehicle } \\
\text { ratio }\end{array}$ \\
\hline \multicolumn{4}{|l|}{5 minutes } \\
\hline$M d r 1 a^{+/+} / 1 b^{+/+}$ & $3.5 \pm 1.5$ & $24.1 \pm 4.8^{\mathrm{A}}$ & 6.9 \\
\hline$M d r 1 a^{+/-} / 1 b^{+/-}$ & $4.3 \pm 1.9$ & $23.1 \pm 5.5^{\mathrm{A}}$ & 5.4 \\
\hline$M d r 1 a^{-/-} / 1 b^{-/-}$ & $16.5 \pm 7.2$ & $23.7 \pm 5.6$ & 1.4 \\
\hline Plasma & $429 \pm 32$ & $1297 \pm 247^{B}$ & 3.0 \\
\hline \multicolumn{4}{|l|}{15 minutes } \\
\hline$M d r 1 a^{+/+} / 1 b^{+/+}$ & $4.2 \pm 0.6$ & $26.3 \pm 8.9^{B}$ & 6.3 \\
\hline$M d r 1 a^{+/-} / 1 b^{+/-}$ & $4.4 \pm 1.0$ & $20.9 \pm 6.2^{\mathrm{A}}$ & 4.8 \\
\hline$M d r 1 a^{-/-/ 1 b^{-/-}}$ & $21.1 \pm 3.4$ & $26.0 \pm 6.8^{c}$ & 1.2 \\
\hline Plasma & $146 \pm 16$ & $790 \pm 195^{\mathrm{B}}$ & 5.4 \\
\hline
\end{tabular}

Results are presented as mean $\pm \mathrm{SD}$ in $\mathrm{ng}\left[{ }^{14} \mathrm{C}\right]$ saquinavir equivalent per gram or per $\mathrm{mL}$ Four pregnant $\mathrm{Mdr} \mathrm{a}^{+/-} / 1 \mathrm{~b}^{+/-}$dams at gestation day 15 received PSC833 $(50 \mathrm{mg} / \mathrm{kg}$ ) or vehicle alone by gavage 2 hours before intravenous injection of $\left[{ }^{14} \mathrm{C}\right]$ saquinavir at 1 $\mathrm{mg} / \mathrm{kg}$. Data presented in Figure 2 for vehicle-treated dams are included in this table for comparison. ${ }^{A} P<0.0005,{ }^{B} P<0.01,{ }^{C} P<0.05$ vs. vehicle-treated mice. Four to 27 fetuses of each genotype were analyzed.

genotypes, to a level similar to that observed in vehicletreated $M d r 1 a / 1 b$ null fetuses (Table 3 ). This was observed at both 5 and 15 minutes after intravenous $\left[{ }^{14} \mathrm{C}\right]$ saquinavir administration. This indicates that $\left[{ }^{14} \mathrm{C}\right]$ saquinavir can readily pass the placenta if a potent P-gp inhibitor is present in the maternal plasma. However, PSC833 also decreased maternal $\left[{ }^{14} \mathrm{C}\right]$ saquinavir plasma clearance considerably, leading to 3- to 5-fold increased plasma values at the time points analyzed, which complicates interpretation of the fetal distribution data. Determination of the unchanged plasma saquinavir levels showed that after just 5 minutes, less than $20 \%$ of plasma radioactivity represented the parent compound. The unchanged saquinavir plasma levels at both 5 and 15 minutes after intravenous administration to vehicle- and PSC833-pretreated dams differed less (about 2- to 3-fold) than the levels of total radioactivity. It was, however, not feasible to determine the amounts of unchanged saquinavir in the fetuses due to the low saquinavir levels and the small sample size.

Higher levels of exposure to $\left[{ }^{14} \mathrm{C}\right]$ saquinavir might lead to saturation of the P-gp transport capacity in the placenta, which could contribute to the increased saquinavir penetration into the fetus (Table 3). We therefore investigated fetal distribution of $\left[{ }^{14} \mathrm{C}\right]$ saquinavir at a 5-fold higher drug dosage (5 $\mathrm{mg} / \mathrm{kg}$ ). The maternal plasma level at this high dose was approximately $800 \mathrm{ng} / \mathrm{mL}$ at 15 minutes after intravenous drug administration (Table 4), almost identical to the plasma level observed after $15 \mathrm{~min}$ utes, when PSC833 and $\left[{ }^{14} \mathrm{C}\right]$ saquinavir $(1 \mathrm{mg} / \mathrm{kg})$ were coadministered (Table 3). At the same time, the relative fetal $\left[{ }^{14} \mathrm{C}\right]$ saquinavir ratios for the different genotypes (with a 7-fold higher concentration in $M d r 1 a / 1 b$ null than in wildtype fetuses) were similar to the $\left[{ }^{14} \mathrm{C}\right]$ saquinavir ratios found in fetuses after the $1 \mathrm{mg} / \mathrm{kg}$ saquinavir administration (compare Tables 3 and 4). This

\section{Table 5}

Table 4

Maternal plasma and fetal tissue levels of radioactivity 15 minutes after intravenous administration of $\left[{ }^{14} \mathrm{C}\right]$ saquinavir $(5 \mathrm{mg} / \mathrm{kg})$

$\begin{array}{lc} & {\left[{ }^{14} \mathrm{C}\right] \text { saquinavir level }} \\ M d r 1 a^{+/+} / 1 b^{+/+} & 18.3 \pm 5.1 \\ M d r 1 a^{+/-} / 1 b^{+/-} & 22.8 \pm 13.4 \\ M d r 1 a^{-/-} / 1 b^{-/-} & 130.6 \pm 19.9{ }^{A} \\ \text { Plasma } & 796 \pm 50\end{array}$

Results are presented as mean $\pm \mathrm{SD}$ in $\mathrm{ng}\left[{ }^{14} \mathrm{C}\right]$ saquinavir equivalent per $\mathrm{mL}$ or per gram. Four pregnant $M d r 1 a^{+/-} / 1 b^{+/-}$dams at gestation day 15 received vehicle by gavage 2 hours before the injection of $\left[{ }^{14} \mathrm{C}\right]$ saquinavir $(5 \mathrm{mg} / \mathrm{kg}) .{ }^{A} P<0.0001 \mathrm{vs}$. wild-type fetuses. Ten to 22 fetuses of each genotype were analyzed.

indicates that the placental P-gp was not at all saturated by the higher plasma drug concentrations.

GG918 is a selective and potent inhibitor of MDR1 P$\mathrm{gp}$, and unlike PSC833, it has very little interaction with cytochrome P450-mediated drug metabolism $(23,24)$. We therefore investigated the influence of GG918 $(25 \mathrm{mg} / \mathrm{kg}$, administered orally 2 hours before saquinavir administration) on the fetal distribution of $\left[{ }^{14} \mathrm{C}\right]$ saquinavir. In contrast to PSC833, GG918 did not influence maternal $\left[{ }^{14} \mathrm{C}\right]$ saquinavir plasma levels (Table 5). At the same time, GG918 treatment did result in equal distribution of $\left[{ }^{14} \mathrm{C}\right]$ saquinavir to all fetuses, irrespective of genotype. Once again, $\left[{ }^{14} \mathrm{C}\right]$ saquinavir levels in the GG918-treated fetuses were similar to those in vehicle-treated $M d r 1 a / 1 b$ null fetuses, and were at least 5-fold higher than those in vehicle-treated wild-type fetuses.

\section{Discussion}

In this study we demonstrate that the placental drugtransporting P-gp can profoundly limit the passage of various potentially toxic or therapeutically beneficial Pgp substrate drugs into the fetus. We further show that this placental P-gp can be completely blocked by orally administered PSC833 or GG918, resulting in greatly increased transplacental passage of drugs into the fetus. Previously, Lankas et al. showed that the absence of Mdr1a P-gp in the placenta of naturally occurring Mdr1a mutant fetuses is associated with increased fetal accumulation and toxicity of the pesticide avermectin (13). Taken together, the data demonstrate that the mouse Mdr1a P-gp makes a major contribution to yet another biologically important protective barrier. The list now includes the blood-brain barrier, the blood-nerve barrier, the blood-testis barrier, the maternal-fetal barrier, and

Effect of GG918 on maternal plasma and fetal tissue levels of radioactivity 15 minutes after intravenous administration of $\left[{ }^{14} \mathrm{C}\right]$ saquinavir

\begin{tabular}{lccc}
\hline$\left[{ }^{14} \mathrm{C}\right]$ saquinavir + vehicle & {$\left[{ }^{14} \mathrm{C}\right]$ saquinavir + GG918 } & $\begin{array}{c}\text { GG918/vehicle } \\
\text { ratio }\end{array}$ \\
$1 a^{+/+} / 1 b^{+/+}$ & $4.2 \pm 0.6$ & $21.7 \pm 7.4^{\mathrm{A}}$ & 5.1 \\
$1 a^{+/-/ 1 b^{+/-}}$ & $4.4 \pm 0.9$ & $24.1 \pm 6.5^{\mathrm{B}}$ & 5.5 \\
$1 a^{-/-/ 1 b^{-/-}}$ & $21.1 \pm 3.4$ & $27.7 \pm 6.8^{\mathrm{C}}$ & 1.3 \\
sma & $146 \pm 16.0$ & $157 \pm 23.3$ & 1.1 \\
\hline
\end{tabular}

Results are presented as mean $\pm \mathrm{SD}$ in $\mathrm{ng}\left[{ }^{14} \mathrm{C}\right]$ saquinavir equivalent per gram or per $\mathrm{mL}$. Four pregnant Mdr1 $\mathrm{a}^{+/-} / 1 \mathrm{~b}^{+/-}$dams at gestation day 15 received GG918 $(25 \mathrm{mg} / \mathrm{kg})$ or vehicle alone by gavage 2 hours before the intravenous injection of $\left[{ }^{14} \mathrm{C}\right]$ saquinavir $(1 \mathrm{mg} / \mathrm{kg}) .{ }^{A} P<0.005,{ }^{B} P<0.0001,{ }^{C} P<0.05$ vs. vehicle-treated mice. Four to 26 fetuses of each genotype were analyzed. 
the intestinal barrier $(10,12,13,25-28)$. Thus, P-gp activity protects the central blood circulation and a range of tissue compartments that are highly vulnerable to toxic insult - including the fetus - from penetration of amphipathic xenotoxins.

Because MDR1 P-gp can be detected in human placental trophoblasts from the first trimester of pregnancy to full term $(25,28-31)$, it is very likely that the placental drug-transporting P-gp protects the developing embryo and fetus from toxic insult in humans as well. Pgp functional activity might even be present in preimplantation embryos, as has been described for mice (32). It is evident that placental P-gp function may have implications for drug therapy of pregnant women. Drugs that are poor P-gp substrates will reach the fetus more easily than those that are good P-gp substrates, other factors being equal. Fetal tolerance to a certain level of maternal exposure to good P-gp substrates will be higher than for equivalent amounts of drugs that are poor P-gp substrates. Thus, when the choice is available, it is preferable to treat pregnant women with drugs that are good P-gp substrates. For instance, in the case of antineoplastic chemotherapy of pregnant women, paclitaxel might be preferred over other cytotoxic anticancer drugs that more easily pass the placenta.

Our data show that it may not always be easy to predict to what extent a P-gp substrate drug will be affected by placental P-gp. Digoxin penetration was affected only 2.2- to 2.4-fold by placental P-gp, and compared to saquinavir and paclitaxel, digoxin entered fetal tissue rather easily in wild-type fetuses. The intermediate digoxin accumulation observed in heterozygous fetuses further suggested that placental P-gp was close to saturation under the conditions used. This is surprising because digoxin is a very good P-gp substrate drug both in vitro and in vivo $(17,22,33-35)$. The relatively high penetration of digoxin through the placenta could be due to physicochemical properties of the drug, or to other factors, including the presence of carrier proteins in the placenta that facilitate the transfer of digoxin.

The feasibility of effective pharmacological blocking of placental P-gp function may be of great importance for the pharmacotherapy of pregnant women, because in some cases it is desirable to increase penetration of drugs into the unborn child. An example is the anti-HIV treatment of HIV-infected pregnant women. A substantial percentage $(-25 \%)$ of the children of these mothers become infected with HIV, and most of these infections $(\sim 80 \%)$ appear to occur during late pregnancy and (particularly) birth (36). Preloading of the infant before birth with effective anti-HIV drugs might well have an important prophylactic effect; the HIV reverse transcriptase inhibitor azidothymidine (AZT; or zidovudine) is already used according to this rationale (37). However, the HIV protease inhibitors, which are considered to be more effective drugs, do not appreciably cross the placenta (37), and are therefore unsuitable for this purpose. Placental P-gp is probably an important factor in this low penetration. The results from our study suggest that it may be worthwhile to use coadministration of effective P-gp inhibitors such as GG918 or PSC833 with saquinavir (and possibly other HIV protease inhibitors) during the late stages of pregnancy, in order to increase infant loading with the drugs, and thereby improve prophylaxis. By applying this principle only late during pregnancy, one would hope to limit adverse effects of the increased drug accumulation on development of the infant. Obviously, the feasibility, safety, and efficacy of this procedure should be tested carefully in preclinical models and clinical practice. For example, differences between effects of placental P-gp on drug penetration into human and murine fetuses might arise from differences in substrate specificity between human MDR1 Pgp and murine Mdr1a and Mdr1b P-gp (38).

Our data show that in mice, the cyclosporin A analogue PSC833 has a strong inhibitory effect on maternal saquinavir clearance, leading to increased plasma drug levels. This effect is probably due to inhibition of cytochrome P450-mediated saquinavir metabolism, and this must be taken into account when applying coadministration regimens in pregnant women, because it may lead to unplanned overexposure of the mother. On the other hand, increased maternal exposure is sometimes desirable. Coadministration of the HIV protease inhibitors saquinavir and ritonavir is clinically favorable as it leads to enhanced saquinavir plasma levels, mainly because ritonavir is an effective cytochrome $\mathrm{P} 450$ inhibitor (39). If increased maternal drug exposure is unwanted in a pregnant woman, our data indicate that coadministration of the more specific P-gp inhibitor GG918 is probably a better choice.

These considerations also raise the question of whether currently used coadministrations of drugs might not harbor the risk of partial blocking of placental P-gp by one drug, leading to unintended increases in exposure of the fetus to coadministered drugs. Although in our experience high dosages of very effective P-gp inhibitors are needed to obtain substantial inhibition of P-gp at blood-tissue barrier sites (22, 40, this study), it is still advisable to be alert for unexpected fetal toxicities during drug coadministration regimens.

\section{Acknowledgments}

We thank J.W. Jonker for his technical assistance and our colleagues for critical reading of the manuscript. We are grateful to R.M.W. Hoetelmans for determining saquinavir levels in plasma. We thank Novartis Pharma Inc. and GlaxoWellcome for generous gifts of PSC833 and GG918, respectively. This work was supported in part by grant NKI 97-1434 from the Dutch Cancer Society (to A.H. Schinkel).

1.Juliano, R.L., and Ling, V. 1976. A surface glycoprotein modulating drug permeability in Chinese hamster ovary cell mutants. Biochim. Biophys. Acta. 455:152-162.

2. Higgins, C.F. 1992. ABC transporters: from microorganisms to man. Annu. Rev. Cell Biol. 8:67-113.

3. Gottesman, M.M., and Pastan, I. 1993. Biochemistry of multidrug resistance mediated by the multidrug transporter. Annu. Rev. Biochem. 62:385-427.

4. Gros, P., Ben Neriah, Y.B., Croop, J.M., and Housman, D.E. 1986. Isolation and expression of a complementary DNA that confers multidrug resistance. Nature. 323:728-731.

5. Devault, A., and Gros, P. 1990. Two members of the mouse mdr gene family confer multidrug resistance with overlapping but distinct drug specificities. Mol. Cell. Biol. 10:1652-1663.

6. Thiebaut, F., et al. 1987. Cellular localization of the multidrug-resistance gene product P-glycoprotein in normal human tissues. Proc. Natl. Acad. Sci. USA. 84:7735-7738.

7. Song, R., Ikeguchi, M., Zhou, G., and Kuo, M.T. 1995. Identification and 
characterization of a hepatoma cell-specific enhancer in the mouse multidrug resistance mdr1b promoter. J. Biol. Chem. 270:25468-25474.

8. Croop, J.M., et al. 1989. The three mouse multidrug resistance ( $m d r)$ genes are expressed in a tissue-specific manner in normal mouse tissues. Mol. Cell. Biol. 9:1346-1350.

9. Schurr, E., Raymond, M., Bell, J.C., and Gros, P. 1989. Characterization of the multidrug resistance protein expressed in cell clones stably transfected with the mouse mdr1 cDNA. Cancer Res. 49:2729-2733.

10. Schinkel, A.H., et al. 1994. Disruption of the mouse mdr1a P-glycoprotein gene leads to a deficiency in the blood-brain barrier and to increased sensitivity to drugs. Cell. 77:491-502.

11. Sparreboom, A., et al. 1997. Limited oral bio-availability and active epithelial excretion of paclitaxel (taxol) caused by P-glycoprotein in the intestine. Proc. Natl. Acad. Sci. USA. 94:2031-2035.

12. Kim, R.B., et al. 1998. The drug transporter P-glycoprotein limits oral absorption and brain entry of HIV-1 protease inhibitors. J. Clin. Invest. 101:289-294.

13. Lankas, G.R., Wise, L.D., Cartwright, M.E., Pippert, T., and Umbenhauer, D.R. 1998. Placental P-glycoprotein deficiency enhances susceptibility to chemically induced birth defects in mice. Reprod. Toxicol. 12:457-463.

14. Umbenhauer, D.R., et al. 1997. Identification of a P-glycoprotein-deficient subpopulation in the CF-1 mouse strain using a restriction fragment length polymorphism. Toxicol. Appl. Pharmacol. 146:88-94.

15. Lankas, G.R., Cartwright, M.E., and Umbenhauer, D. 1997. P-glycoprotein deficiency in a subpopulation of CF-1 mice enhances avermectininduced neurotoxicity. Toxicol. Appl. Pharmacol. 143:357-365.

16. Schinkel, A.H., et al. 1997. Normal viability and altered pharmacokinetics in mice lacking mdr1-type (drug transporting) P-glycoproteins. Proc. Natl. Acad. Sci. USA. 94:4028-4033.

17. Mayer, U., et al. 1996. Substantial excretion of digoxin via the intestinal mucosa and prevention of long-term digoxin accumulation in the brain by the mdr1a P-glycoprotein. Br. J. Pharmacol. 119:1038-1044.

18. Wiltshire, H.R., et al. 1998. The synthesis of labelled forms of saquinavir. J. Labelled Cpd. Radiopharm. 41:1103-1126.

19. Van Heeswijk, R.P., et al. 1998. Simultaneous quantitative determination of the HIV protease inhibitors amprenavir, indinavir, nelfinavir, ritonavir and saquinavir in human plasma by ion-pair high-performance liquid chromatography with ultraviolet detection. J. Chromatogr. B. Biomed. Sci. Appl. 719:159-168

20. Kim, A.E., Dintaman, J.M., Waddell, D.S., and Silverman, J.A. 1998. Saquinavir, an HIV protease inhibitor, is transported by P-glycoprotein. J. Pharmacol. Exp. Ther. 286:1439-1445.

21. Lee, C.G., et al. 1998. HIV-1 protease inhibitors are substrates for the MDR1 multidrug transporter. Biochemistry. 37:3594-3601.

22. Mayer, U., et al. 1997. Full blockade of intestinal P-glycoprotein and extensive inhibition of blood-brain barrier P-glycoprotein by oral treatment of mice with PSC833. J. Clin. Invest. 100:2430-2436.

23. Hyafil, F., Vergely, C., Du Vignaud, P., and Grand-Perret, T. 1993. In vitro and in vivo reversal of multidrug resistance by GF120918, an acridonecarboxamide derivative. Cancer Res 53:4595-4602.

24. Wallstab, A., Koester, M., Böhme, M., and Keppler, D. 1999. Selective inhibition of MDR1 P-glycoprotein-mediated transport by the acridone carboxamide derivative GG918. Br. J. Cancer. 79:1053-1060.

25. Cordon-Cardo, C., et al. 1989. Multidrug-resistance gene (P-glycoprotein) is expressed by endothelial cells at blood-brain barrier sites. Proc. Natl. Acad. Sci. USA. 86:695-698.

26. Saito, T., et al. 1997. P-glycoprotein expression in capillary endothelial cells of the $7^{\text {th }}$ and $8^{\text {th }}$ nerves of guinea pig in relation to blood-nerve barrier sites. Neurosci. Lett. 232:41-44.

27. Jonker, J.W., et al. 1999. Role of blood-brain barrier P-glycoprotein in limiting brain accumulation and sedative side-effects of asimadoline, a peripherally acting analgesic drug. Br.J. Pharmacol. 127:43-50.

28. Nakamura, Y., et al. 1997. Function of P-glycoprotein expressed in placenta and mole. Biochem. Biophys. Res. Commun. 235:849-853.

29. Sugawara, I., et al. 1988. Tissue distribution of P-glycoprotein encoded by a multidrug-resistant gene as revealed by a monoclonal antibody, MRK 16. Cancer Res. 48:1926-1929.

30. Van Kalken, C.K., et al. 1992. Multidrug resistance gene (P-glycoprotein) expression in the human fetus. Am. J. Pathol. 141:1063-1072.

31. MacFarland, A., Abramovich, D.R., Ewen, S.W.B., and Pearson, C.K. 1994. Stage-specific distribution of P-glycoprotein in first-trimester and full-term human placenta. Histochem. J. 26:417-423.

32. Elbling, L., Berger, W., Rehberger, A., Waldhor, T., and Micksche, M. 1993. P-glycoprotein regulates chemosensitivity in early developmental stages of the mouse. FASEB J. 7:1499-1506.

33. De Lannoy, I.A.M., and Silverman, M. 1992. The MDR1 gene product, Pglycoprotein, mediates the transport of the cardiac glycoside, digoxin. Biochem. Biophys. Res. Commun. 189:551-557.

34. Tanigawara, Y., et al. 1992. Transport of digoxin by human P-glycoprotein expressed in a porcine kidney epithelial cell line (LLC-PK1). J. Pharmacol. Exp. Ther. 263:840-845.

35. Schinkel, A.H., Wagenaar, E., van Deemter, L., Mol, C.A., and Borst, P. 1995. Absence of the mdr1a P-glycoprotein in mice affects tissue distribution and pharmacokinetics of dexamethasone, digoxin, and cyclosporin A. J. Clin. Invest. 96:1698-1705.

36. Newell, M.-L. 1998. Mechanism and timing of mother-to-child transmission of HIV-1. AIDS. 12:831-837.

37. Casey, B.M., and Bawdon, R.E. 1998. Placental transfer of ritonavir with zidovudine in the ex vivo placental perfusion model. Am. J. Obstet. Gynecol. 179:758-761.

38. Tang-Wai, D.F., et al. 1995. Human (MDR1) and mouse (mdr1, mdr3) P-glycoproteins can be distinguished by their respective drug resistance profiles and sensitivity to modulators. Biochemistry. 34:32-39.

39. Merry, C., et al. 1997. Saquinavir pharmacokinetics alone and in combination with ritonavir in HIV-infected patients. AIDS. 11:F29-F33.

40. Hendrikse, N.H., et al. 1998. Complete in vivo reversal of P-glycoprotein pump function in the blood-brain barrier visualized with positron emission tomography. Br. J. Pharmacol. 124:1413-1418. 